\title{
Obscure and mysterious symptom in multiple sclerosis: Pathological laughing and crying
}

\section{Multipl skleroz'da izlenen okkult ve nadir semptom: Patolojik ağlama ve gülme}

Özge Arıcı Düz ${ }^{1}$, İlknur Aydın Cantürk ${ }^{2}$, Miraç Ayşen Ünsal Çakmak ${ }^{3}$, Nihal Ișıl ${ }^{4}$, Nesrin Helvacı Yılmaz ${ }^{1}$

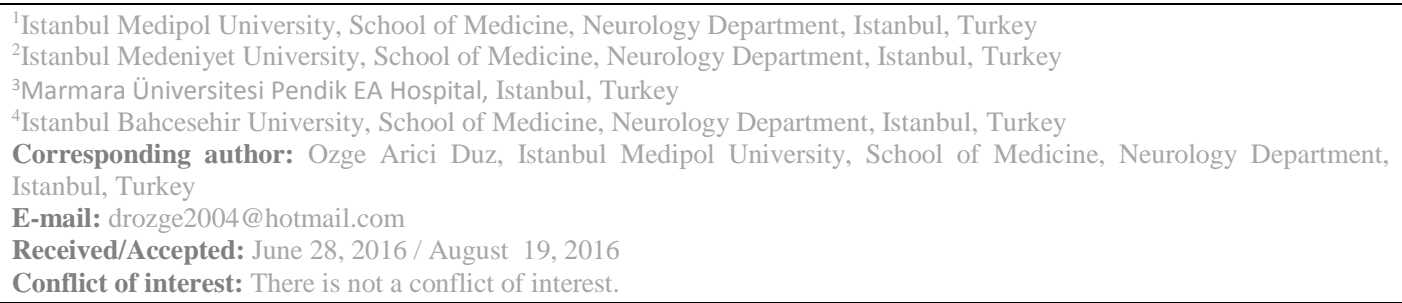

\section{SUMMARY}

Pathological laughing and crying (PLC) has an approximately prevelance of $7 \%-10 \%$ among patients with multiple sclerosis (MS). Various damages of prefrontal, temporal cortex, internal capsule, hypothalamus, thalamus, brainstem and the cerebellar pathways may cause pathological laughing or crying. We interviewed 160 MS patients for PLC. Only 5 of our 160 cases complained about pathological laughing or crying. All 5 patients had PLC defined as sudden, involuntary displays of laughing or crying or both, without associated subjective feelings of depression or euphoria. Patient group, consisting 2 women and 3 men had a mean age of 41, mean Expanded Disability Status Scale (EDSS) score of 4.8, disease duration of 12.8 years. In our patients PLC was not associated with disease exacerbations. All PLC patients had numerous brainstem and cerebellar relapses, which caused obvious disabilities including gait ataxia, intention tremor, dysmetria, dysarthria, nystagmus and other cerebellar dysfunctions. All of our patients had so many lesions especially in brainstem because of this we think that the brainstem lesions have crucial role in PLC. This hypothesis needs further investigation especially in functional imaging which may add further information to pathogenesis of PLC. Before the investigation of PLC none of our patients informed us about their complaints of PLC so the physician must be aware of this symptom.

Keywords: pathological laughing and crying, multiple sclerosis, MRI

ÖZET

Patolojik ağlama ve gülme (PLC), multipl skleroz (MS) hastalarında yaklașık \%7-10 oranında görülür. Prefrontal, temporal korteks, internal kapsül, hipotalamus, talamus, beyinsap1 ve serebellar yolaklarda gelişebilecek çeşitli nedenli hasarlar patolojik ağlama ve gülmeye neden olabilir. $160 \mathrm{MS}$ hastasını PLC açısından sorguladık. 160 hastanın sadece 5'i PLC'den yakındı. 5 hastada da PLC; depresyon ya da öfori olmadan, koşullarla uyumsuz, ani, istemsiz ağlama, gülme ya da ikisinin birden varlığı olarak tanımlandı. Hasta grubunda 2 kadın, 5 erkek olmak üzere toplam var olan 5 hastanın ortalama yaşı 41, ortalama EDSS skoru 4.8, ortalama hastalık süresi 12.8 yıldı. Hastalar atak döneminde değildi. Çalışmamızdaki tüm PLC hastalarında ataksi, intansiyonel tremor, dismetri, dizartri, nistagmus ve diğer serebellar system disfonksiyon bulgularına neden olan çeşitli sayıda beyin sapı ve serebellar system atak öyküsü mevcuttu. PLC tanımlanan tüm hastalarda özellikle 
beyin sapında çok sayıda lezyon mevcuttu, bu nedenle beyin sapının anatomic olarak PLC'de önemli olduğu düşünüldü. Ancak bu hipotez daha fazla sayıda hastada yapılacak olan fonksiyonel görüntüleme çalışmaları ile desteklenmesi gerektiği düşünüldü. Hastaların hiçbiri sorgulama öncesi PLC'den yakınmadığı için klinisyenbu semptomun farkında olmalıdır.

Anahtar sözcükler: Multipl skleroz, patolojik gülme ve ağlama, MRI

\section{INTRODUCTION}

Pathological laughing and crying (PLC) is a clinical condition which seen episodically as involuntary, exaggerated laughter or crying in any inappropriate occasion. PLC, known as "Fou rire prodromique" has an approximately prevalence $49 \%$ with amyotrophic lateral sclerosis (ALS), 36\% with multiple system atrophy, $10 \%-20 \%$ with stroke, 4-6\% with Parkinson's disease and 7\%$10 \%$ with $\mathrm{MS}^{1}$. For being an out of ordinary symptom and therefore developing social disability, its pathophysiology has been studied for years. Yet the anatomy of pathological laughing is still unknown, further investigation is needed to determine the certain localization. This paper highlights five cases of (PLC) in (MS); for better understanding its correlation with the clinical course and magnetic resonance imaging (MRI) findings.

We interviewed 160 clinically or laboratory definite MS patients for any complain of PLC. We have found PLC in five patients. They are documented according to; age, gender, physical disability (EDSS), clinical feature, MRI and duration of the disease.

CASE 1: 32 years-old, male patient diagnosed in 1996 as MS. The first symptoms of disease were ataxia, nystagmus and dysarthria. He has had three more relapses affecting in each of brainstem, pyramidal system, and spinal cord. The course of the disease was progressive since 2003 and his EDSS was 6.0. The MRI showed numerous MS plaques and atrophy especially in brainstem. PLC was observed 8 years after the disease onset when he was in progressive phase.

CASE 2: A 50 year-old male was diagnosed as MS in 1987 and he have had seventeen relapses. Eight of the relapses were involving brainstem. His EDSS was 4.5 and MRI showed many cranial MS plaques, especially in brainstem and cerebellum with mild, global cortical atrophy. PLC was observed 17 years after the disease onset when he was in progressive phase.

CASE 3: 31 year-old male patient; diagnosed in 2002 as multiple sclerosis. $\mathrm{He}$ had four MS relapses affecting spinal cord, pyramidal system and brainstem and only one of the relapses was involving the brainstem. His EDSS was 4.0. PLC was observed 10 years after the disease onset. Brainstem lesions were seen in MRI at the first relapse of the disease which were localized at basis pontis.

CASE 4: A 49 year-old female with a 24 years history of MS had seven relapses, mostly affecting brainstem and spinal cord. She has been in progressive phase since 2002. Her EDSS was 6.0. PLC was observed 20 years after the disease onset when she was in progressive phase.

CASE 5: A 43 year old male who was under diagnosis as MS for 14 years, had first exacerbation of disease with ataxia. $\mathrm{He}$ had three relapses which were localized at brainstem. His EDSS was still 3.5 an in progressive course for nearly one year. PLC was observed 13 years after the disease onset when he was in progressive phase 
Table 1. Characteristics of the cases.

\begin{tabular}{|c|c|c|c|c|c|}
\hline & Case 1 & Case 2 & Case 3 & Case 4 & Case 5 \\
\hline \multicolumn{6}{|l|}{ Clinical Features } \\
\hline Age at onset of MS & 19 & 27 & 23 & 25 & 29 \\
\hline Gender & $\mathrm{M}$ & $\mathrm{M}$ & $\mathrm{M}$ & $\mathrm{F}$ & $\mathrm{M}$ \\
\hline Disease duration & 17 years & 23years & 8 years & 24 years & 15 years \\
\hline Inıtial symptom & $\begin{array}{c}\text { Ataxia, } \\
\text { nystagmus, } \\
\text { dysarthria }\end{array}$ & $\begin{array}{l}\text { Monoparezi } \\
\text { at left leg, } \\
\text { ataxia }\end{array}$ & Ataxia & Ataxia & Ataxia \\
\hline Disease course & $\begin{array}{l}\text { Progresive } \\
\text { MS }\end{array}$ & $\begin{array}{c}\text { Progresive } \\
\text { MS }\end{array}$ & $\begin{array}{c}\text { Relapsing } \\
\text { remitting } \\
\text { MS }\end{array}$ & $\begin{array}{l}\text { Progresive } \\
\text { MS }\end{array}$ & $\begin{array}{l}\text { Progresive } \\
\text { MS }\end{array}$ \\
\hline Number of relapse & 3 & 17 & 4 & 7 & 8 \\
\hline $\begin{array}{l}\text { Number of brain } \\
\text { stem relapse }\end{array}$ & 1 & 8 & 1 & 2 & 3 \\
\hline EDSS & 6.0 & 4.5 & 3.5 & 6.0 & 4.5 \\
\hline $\begin{array}{l}\text { Time of PLC onset } \\
\text { after MS diagnosis } \\
\text { (years) }\end{array}$ & 8 & 17 & 6 & 20 & 13 \\
\hline \multicolumn{6}{|l|}{ MRI } \\
\hline Atrophy & + & + & - & + & + \\
\hline Brainstem lesion & + & + & + & + & + \\
\hline Temporal lob lesion & + & - & - & + & - \\
\hline
\end{tabular}

\section{DISCUSSION}

MS is a neurodegenerative disorder of central nervous system. The symptom spectrum of disease is extensive. Beside well-known symptoms such as weakness, gait disturbances; PLC is usually unrecognized by clinicians.

The studies were described many anatomic locations about PLC. Oppenheim and Simmering described the first cases in 1886 with lesions in brainstem along the descending pathways $^{2}$. In 1924 Wilson assumed the existence of a "facio-respiratory center" located in the brainstem to explain the pathogenesis of laughter ${ }^{3}$. Other authors remarked the medial thalamus, subthalamus, hypothalamus or anterior limb of internal capsule as the center of (PLC) $)^{4,5}$. Within the near past decades, many of the modern studies indicated two partially independent neuronal pathways. The first pathway involves the amygdala, thalamic, hypothalamic area, subthalamic area and the dorsal brainstem known as involuntary system $^{6,7}$. The second is the voluntary system which originates in the premotorfrontal opercular areas and leads through the motor cortex and pyramidal tract to the ventral brainstem ${ }^{8}$. In all of our patients diffuse brainstem, cerebellum and periventricular lesions are documented on MRI. Patient group was consisting of 2 women and 3 men and had a mean age of 41 (31-50), mean Expanded Disability Status Scale (EDSS) score of 4.8 (3.5-6.0), disease duration of 12.8 (6-21) years. We observed that all patients had numerous brainstem relapses, which caused obvious disabilities including ataxia, intention tremor, dysmetria, dysarthria, nystagmus and other cerebellar dysfunctions and these symptoms were major factor in disability. All of the patients were having cerebral and brainstem atrophy. All of our patients had brainstem lesions located at the ventral pons as state as basis pontis. Ventral basal pons, called 'the laughing center', is subject to tonic inhibitory impulses from cortex, limbic 
system and cerebellum via an 'integrator' located in the hypothalamus'. There are some theories suggesting that the PLC is the result of the damage of pathways that arise in the motor areas of the cerebral cortex and descend to the brainstem. Similar with previous studies all of our five patients were progressive phase in MS, and symptom begun at the beginning of the progressive phase. Takado et al, have reported a patient of MS whose MRI showed a lesion in the right pontine base having pathological laughter and hemiparesis as a relapse ${ }^{10}$. His repeated MRI showed a fresh plaque in the left pontine base which made them suggesting that the pontine base lesion was responsible for the (PLC). But none of our patients were in active relapse

\section{REFERENCES}

1. Parvizi J, Arciniegas DB, Bernardini GL, et al. Diagnosis and management of pathological laughter and crying. Mayo Clin Proc 2006; 81: 1482-6.

2. Oppenheim H, Siemerling E. Mitteilungenuber pseudobulbar paralyse und akute Bulbarparalyse. Berlkli Woch 1886; 46.

3. Wilson SA. Some problems in neurology. II: Pathological laughing and crying J Neurol Psychopathol 1924; 4: 299-333.

4. Bechterew W. Die funktionen der Nervencentra. Jena, Fischer 1909.

5. Poeck K. Pathological laughter and crying, in Clinical Neuropsychology 1985; 219: 343-67.

6. Lanteaume L, Khalfa S, Regis J, et al. Emotion induction after direct intracerebral stimulations of human amygdala. Cereb Cortex; 2007; 17: 1307-13

7. Benedetti F, Colloca L, Lanotte M, et al. Autonomic and emotional responses to open and hidden stimulations of the human subthalamic region. Brain Res Bull 2004; 63: 203-11.

8. Parvizi J, Damasio A. The neuroanatomical correlates of brainstem coma. Brain 2003; 126: 1524-36.

9. Larner AJ. Basilar artery occlusion associated with pathological crying: period when they complained about (PLC). After the diagnosis of PLC; all of the patients treated with serotonin reuptake inhibitors but no benefit was observed.

PLC is especially found in the chronic progressive phase of the disease mostly associated with cognitive impairment and brainstem lesions. The physician must aware of the condition and investigate it carefully. Because the MRI findings and clinical features are not as sufficient as clinical signs of PLC. Further information on MRI findings especially on functional imaging will accompany more information about the pathogenesis of PLC.

'folles larmes. prodromiques'? Neurology 1998; 51: 916-7.

10. Takado $\mathrm{Y}$, Igarashi S, Akaiwa $\mathrm{Y}$, Terajima K, Tanaka K, Tsuji S. A case of multiple sclerosis with pathological laughing caused by pontine base lesions. Rinsho Shinkeigaku 2002; 42: 519-22. 